症例

広範な後腹膜膿瘍をきたした $\mathrm{S}$ 状結腸間膜内へルニアの 1 例

\begin{tabular}{|c|c|c|c|c|c|c|c|c|}
\hline \multicolumn{9}{|c|}{ 済生会松阪総合病院外科 } \\
\hline 戸 & 政 & 佳 & 黒 田 & 久 & 弥 & 伊 & 藤 & 彰 \\
\hline 藤 & 憲 & 治 & 加 & 弘 & 幸 & 岩 & 田 & \\
\hline 沼 & 達 & 史 & 佐々木 & 英 & 人 & 藤 & 森 & \\
\hline
\end{tabular}

症例は66歳男性. 入院 3 日前より嘔吐, 腹部膨満, 左陰襄の腫脹をきたし来院. 理学

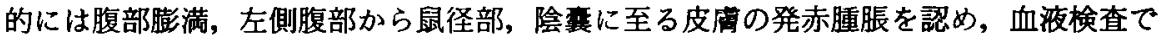
は著明な白血球増多, CRP 高値および腎障害を認めた。腹部 X 線所見では腸閉塞像を呈 し, CT では左腎周囲後腹膜から鼠径部に至る広範な後腹膜膿瘍と左精索の腫大を認め た. 鼠径ヘルニアの嵌頓穿孔による腸閉塞および後腹膜朖瘍の診断にて緊急手術施行. 鼠径ヘルニアはなく, S 状結腸間膜根部付近に間膜欠損部を認め, 同部に回腸が Richter 型に嵌頓穿孔し後腹膜膿瘍を形成していた.S 状結腸間膜内ヘルニアと診断し, 回腸穿孔 部および間膜欠損部を縫合閉鎖し，広範な膿瘍挖ドレナージを施行し救命した．本邦て の S 状結腸間膜ヘルニア報告例は38例にすぎ゙，特に自験例は嵌頓腸管の穿孔，膿煬形 成を来した S 状結腸間膜内へルニアであり，極めて稀な 1 例であった。

索引用語 : S 状結腸間膜内ヘルニア, 皮下膿瘍, 腸閉塞

\section{緒 言}

$\mathrm{S}$ 状結腸間膜に起因するへルニア（以下 S 状結腸間 膜ヘルニア) は内ヘルニアの一種であるが, その頻度 はきわめて稀であり,また特徵的な臨床所見にそしく， 腸閉塞の診断で開腹されはじめて本症と診断されるこ とが多い.今回われわれは, S 状結腸間膜内へルニアの 嵌頓, 穿孔により, 左腎周囲から鼠径部および陰禹に 至る広範な後腹膜膿瘍をきたした 1 例を経験したので 報告する。

$$
\text { 症例 }
$$

患者：66歳, 男性.

主訴：嘔吐, 腹部膨満, 左陰莫腫脹。

既往歴：53歳に脳出血にて手術. 以後左半身麻瘒, 言語障害を認め，54歳頃より養護ホームに入所中で あった。 なお腹部手術, 腹部外傷の既往はない.

現病歴：1996年 4 月 3 日頃より, 嘔吐と腹部膨満を 認め, 同 5 日より左陰要の腫脹も出現してきたため同 6 日当科受診. 鼠径部皮下膿場の診断にて緊急入院と なった。

入院時理学的所見：体温 $36.3^{\circ} \mathrm{C}$, 脈拍 $98 /$ 分, 整, 血

1998年 8 月12日受付 1998年 9 月22日採用
圧112/70mmHg. 負血, 黄㾝なし. 心肺異常所見なし. 腹部は軟であったが全体に膨隆しており，腸動音は減 弱していた。ささらに左側腹部から左鼠径部㧍よび左陰 賈にかけて発赤, 腫脹, 圧痛を認めた。

入院時検查成績：著明な白血球増多, CRP の高值, 軽度の寨血, 低蛋白血症, 高度な腎機能異常および電 解質異常を認めた（表 1 )。

腹部 X 線所見：胃および小腸の著明な抎張を認め, さらに左側の腸腰筋陰影に浻った異常な線状のガス像

表 1 入院時検查成結

\begin{tabular}{|c|c|c|c|}
\hline \multicolumn{2}{|c|}{$\mathrm{O}$ 型, $\mathrm{Rh}(+)$} & GOT & $49 \mathrm{IU} / l$ \\
\hline \multicolumn{2}{|c|}{ HBs-Ag (-) } & GPT & $25 \mathrm{IU} / l$ \\
\hline \multicolumn{2}{|c|}{$\mathrm{HCV} \quad(-)$} & LDH & $359 \mathrm{IU} / l$ \\
\hline \multicolumn{2}{|c|}{ TPHA (-) } & ALP & $31.7 \mathrm{~K} \cdot \mathrm{A}$ \\
\hline \multicolumn{2}{|c|}{ 一般検血 } & $\gamma$-GTP & $307 \mathrm{IU} / l$ \\
\hline WBC & $32,100 / \mathrm{mm}^{3}$ & T-Bil & $0.8 \mathrm{mg} / \mathrm{dl}$ \\
\hline $\mathrm{RBC}$ & $312 \times 10^{4} / \mathrm{mm}^{3}$ & ch-E & $0.36 \Delta \mathrm{PH}$ \\
\hline $\mathrm{Hb}$ & $9.7 \mathrm{~g} / \mathrm{dl}$ & BUN & $105.0 \mathrm{mg} / \mathrm{dl}$ \\
\hline $\mathrm{Ht}$ & $29.7 \%$ & $\mathrm{Cr}$ & $4.0 \mathrm{mg} / \mathrm{dl}$ \\
\hline Plat & $41.9 \times 10^{4} / \mathrm{mm}^{3}$ & $\mathrm{Na}$ & $136 \mathrm{mEq} / \mathrm{l}$ \\
\hline \multicolumn{2}{|c|}{ 血液生化学検且 } & $\mathrm{K}$ & $5.7 \mathrm{mEq} / l$ \\
\hline $\mathrm{TP}$ & $7.8 \mathrm{~g} / \mathrm{dl}$ & $\mathrm{Cl}$ & $102 \mathrm{mEq} / \mathrm{l}$ \\
\hline Alb & $2.2 \mathrm{~g} / \mathrm{dl}$ & CRP & $23.7 \mathrm{mg} / \mathrm{dl}$ \\
\hline
\end{tabular}


を認めた（図 1 ).

腹部単純 CT：腸管の著明な拡張，左腎の結石およ び著明な萎縮を認め, 左堅背側から下方に進展し，左 鼠径部皮下に連続する air を伴う液貯留像を認めた。 さらに左精索の著明な腫脹を認めた（図 2 ).

左鼠径部皮下の試験穿刺にて膿汁が吸引されたた め, 左鼠径へルニアの嵌頓穿孔による腸閉塞および広 範な後腹膜膿湟の診断にて, 同日緊急手術を施行した。

手術所見：まず左鼠径部から側腹部にかけて皮切を

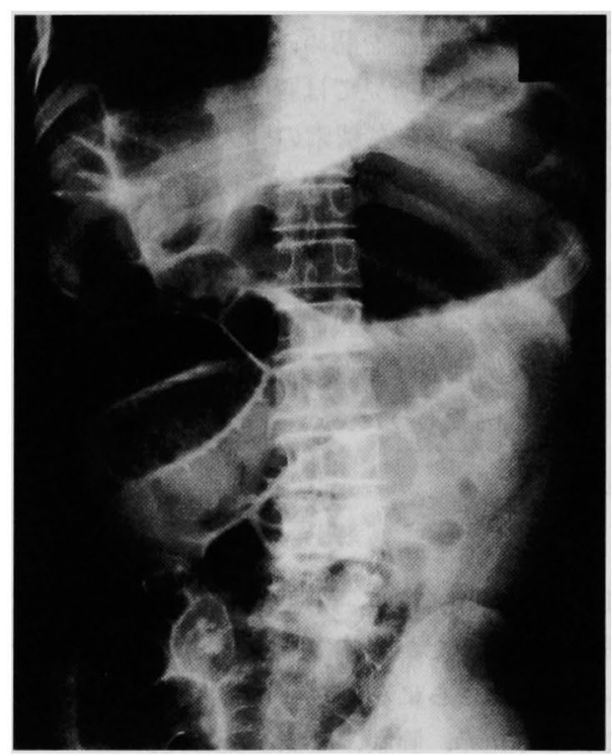

図 1 腹部 $\mathbf{X}$ 線写真：胃, 小腸の著明な拡張および左 腸腰筋陰影に浻った異常な線状のガス像を認める。

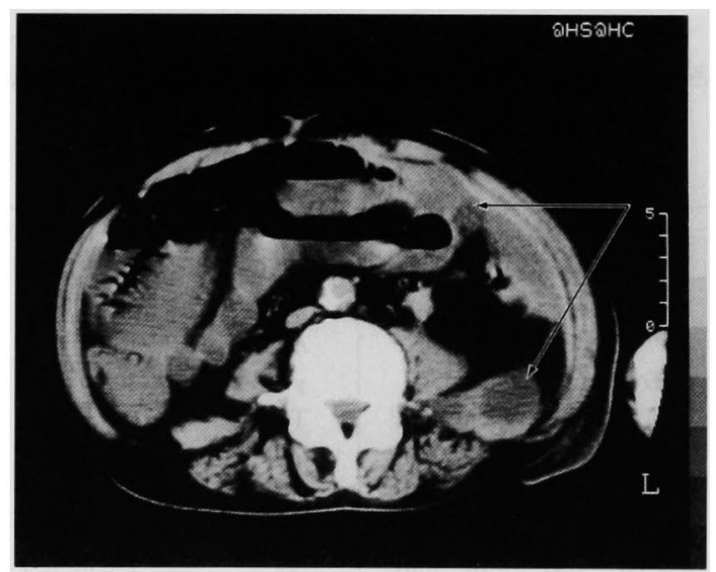

図 2 腹部 CT: 左腎背側の後腹膜から下方に進展 し, 左鼠径部皮下に連続する air を伴う液貯留像を 認める。
加え，鼠徍管を開放したところ，皮下および鼠径管内 より大量の膿汁排出を認めたが, 鼠径ヘルニアはみら れなかった。このため開腹術を行った。

腹腔内には膿や腹水の貯留, free air はなかったが, 回腸末端より約 $90 \mathrm{~cm}$ 口側の回腸が $\mathrm{S}$ 状結腸間膜右葉 の根部，左腎前方の後腹膜と固定されており，これを 㓦離したところ, 間膜根部に径約 $10 \mathrm{~mm}$ の欠損孔を認 め，同部に回腸が Richter 型に嵌頓し，壊死，穿孔を認 めた. 間膜欠損部から下方に連続して後腹膜の膿瘍腔 を認め，さらにこれは鼠径部の浸瘍腔とも連続し交通 していた(図 3，4)。以上より $\mathrm{S}$ 状結腸間膜へルニア (Benson ら"による S 状結腸間膜内へルニア) の岸頓

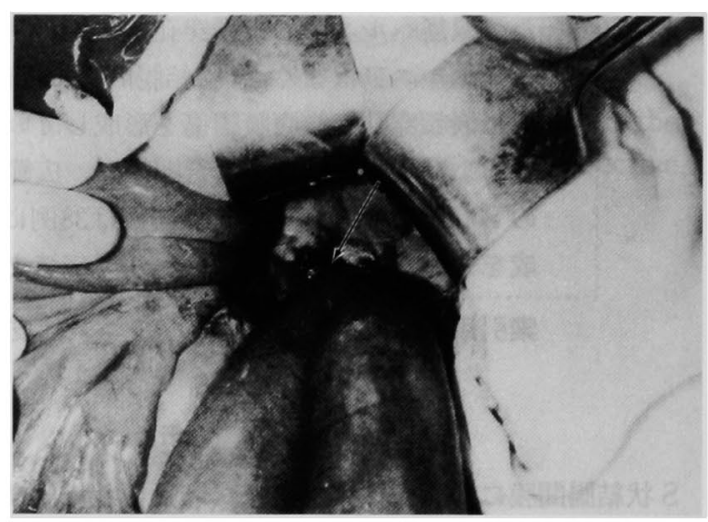

図 3 術中所見 (1)：回腸末端より約 $90 \mathrm{~cm}$ 口側の小 腸が，S 状結腸間膜根部の後腹膜に固定されている (図の左側が頭側)。

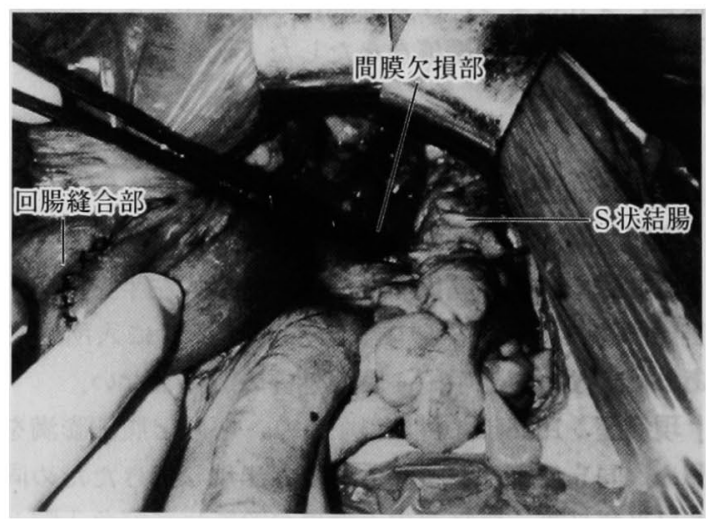

図 4 術中所見 (2)：S 状結腸間膜根部に約 $10 \mathrm{~mm}$ 大 の欠損孔を認め，同部に回腸が Richter 型に嵌頓し ていた．欠損孔から後腹膜の滞瘍腔への連続性を認 めた，回腸穿孔部は縫合閉鎖してある（図の左側が 頭(則). 


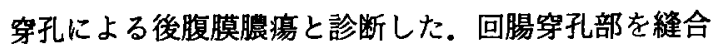
閉鎖し, 間膜欠損部を縫合閉鎖の後閉腹し, 滔径部の 創は開放のまま, 同部から後腹膜腔, 左側腹部および 左陰菨内にドレナージチューブを留置した。

術後すみやかに全身状態の改善が得られた。開放創 の治疮に時間を要したが, 特に大きな合併症なく, 術 後 3 力月目に治庱退院となった. 術後 2 年目の現在生 存中である。

\section{考 察}

開腹歴のない腸閉塞症例の診断に際して, 考虑すべ き疾患として内へルニアがある.内ヘルニアとは，体 腔内の大きな等み, 窝, 陥凹, 裂孔に腸が入ることと 定義され2)，S 状結腸間膜ヘルニアもその1つである.

Hansmann ら $ら^{3} に よ る と ， S$ 状結腸間膜へルニアの 顂度は,すへての内へルニアの約 $5 \%$ と報告されてお ク, 天野4による1987年までの本邦集計では, 内ヘルニ ア315例中16例（5\%）に過ぎず，稀な疾患である.

Benson ら”は, S 状結腸間膜ヘルニアをその形態か ら以下の 3 型に分類している（図 5). すなわち，1. intersigmoid hernia (以下 S 状結腸間膜窝ヘルニア), 2. transmesosigmoid hernia (以下 $\mathrm{S}$ 状結腸間膜裂孔 ヘルニア)，3. intermesosigmoid hernia (以下 S 状結 腸間膜内ヘルニア) である.

$\mathrm{S}$ 状結腸間膜窝へルニアとは, Toldt $の$ fusion fascia の癒合不全により生じた S 状結腸間膜窩 (intersigmoid fossa）に腸管が㑷入するものである.

$\mathrm{S}$ 状結腸間膜裂孔へルニアとは, S 状結腸間膜に穿 通性の欠損があり,ここに腸管が嵌入し腸間膜の反対 側に脱出するものであり，ヘルニア豪を持たない。

$\mathrm{S}$ 状結腸間膜内へルニアとは，S 状結腸間膜の左右 いずれかの片葉に欠損があり，ここから腸管が間膜内 に嵌入するものである。この欠損は先の S 状結腸間膜 窝とは関連せず,またへルニア哓は間膜内に存在する。
Benson ら”の報告例は間膜左葉の欠損であるが，頼藤 ららの報告例の如く，間膜の欠損は右葉にも存在する. なお欠損孔の大きさは記載の明らかな本邦報告例では 通常2〜3cm のものが多い6.

以上の定義に基づいて本邦報告例を分類すると, 本 邦におけるS 状結腸間膜ヘルニア報告(例は, 村上ら の26例に加えわれわれが検索しえた結果38例を数え， $\mathrm{S}$ 状結腸間膜㸗へルニアが(5例 ${ }^{6) ~ 9)}, S$ 状結腸間膜裂孔 ヘルニアが14(列699-10), S 状結腸間膜内ヘルニアが 9

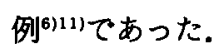

自験例では明らかなへルニア襄はなく，間膜欠損の 大きさも $1 \mathrm{~cm}$ と小さかったが, S 状結腸間膜の右葉に のみ欠損孔を認め, $\mathrm{S}$ 状結腸間膜内から後腹膜に向 かって膿場の形成を認めたことから， S 状結腸間膜内 ヘルニアと最終診断した (図6).

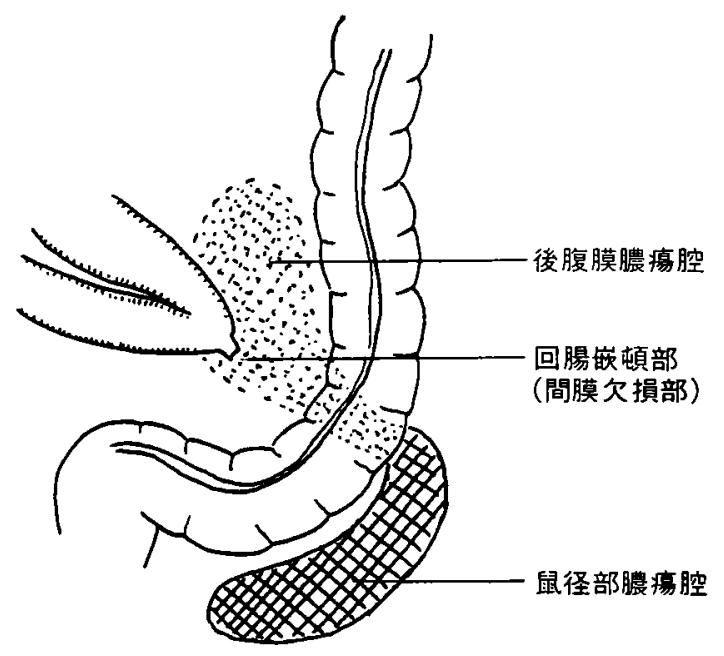

図 6 自験例のシェーマ:S 状結腸間膜右葉の欠損孔 に回腸が Richter 型に嵌頓穿孔し，S 状結腸間膜内 から後腹膜に向かって広範な膿場を形成していた。
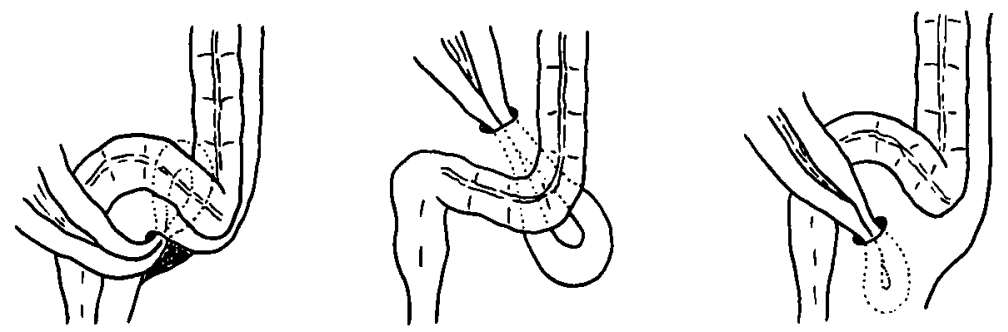

図 $5 \mathrm{~S}$ 状結腸間膜ヘルニアの分類

(Benson ら"の図を改変)

1. intersigmoid hernia, 2. transmesosigmoid hernia, 3. intermesosigmoid hernia 
一方, S 状結腸間膜へルニアの成因については, その ほとんどが先天的要因によると考えられている．S 状 結腸間膜窝は，胎生期における左旁結腸㴗領域ての腸 間膜と壁側腹膜の瘜合不全により生じた鞘状の小腹膜 腔であり ${ }^{121}, \mathrm{~S}$ 状結腸間膜裂孔ては, 腸間膜や血管系の 発育異常が示唆されている ${ }^{15}$. S 状結腸間膜内ヘルニ アに扔ける間膜欠損についても，先天性を示唆する報 告5)がある.

自験例では，過去の S 状結腸間膜内ヘルニア報告例 に比し，次損孔が小さく，さらに，1）脳出血後遺症に よる半身不随のため生じた左側腸腰筋の萎縮,2）腎結 石，慢性腎盂炎による著明な腎萎縮をきたしており， これに伴うS 状結腸間膜の変形の過程で同部に陥凹 や裔が形成され，S 状結腸間膜内ヘルニア発生の原因 となった可能性も考えられた。

$\mathrm{S}$ 状結腸間膜へルニアの症状は, 腹痛, 嘔吐などの腸 閉塞様症状が主体であり 前診断に関しては，斎藤ら ${ }^{9}$ は小腸造影にて S 状結腸 間膜窝へルニアと診断し，中井ら ${ }^{(4)}$ は注腸透視にて腸 間膜ヘルニアを疑ったと報告している。しかし術前診 断は一般的に困難であり，腸閉塞の診断にて手術を施 行し，術中に確定診断される場合がほとんどである。 自験例では左鼠径部から陰辜の発赤, 腫脹を伴う広範 な後腹膜膿場を併発しており，さらに腸閉塞も合併し ていたことから，左鼠径へルニアの嵌頓笔孔と術前診 断したか， retrospective な CT 所見などの検討でも S 状結腸間膜ヘルニアと診断することは容易ではないも のと考えられた，なお自験例の如く，後腹膜に広範な 膿瘍をきたした S 状結腸間膜へルニアは，文献的には 見当たらなかった。

$\mathrm{S}$ 状結腸間膜ヘルニアの治療では，S 状結腸間膜裂 孔へルニアの場合はへルニア毫がなく，急速に嵌入腸 管の壊死や捻転を来すものも多く，腸切除を施行され た症例が多いが(6)，S 状結腸間膜窩へルニアや S 状結 腸間膜内ヘルニアでは，ヘルニア門（間膜欠損部）の 径が比較的大きいものが多く，嵌頓整復およびへル二 ア門の縫合閉鎖のみが施行された症例がほとんどであ る.しかし自験例ではヘルニア門径が小さく，Richter 型に嵌頓し，嵌頓腸管の穿孔を来していたため，広範 な膿漡腔のドレナージと腸管の縫合閉鎖が必要であっ た.

\section{まとめ}

腸管の嵌頓穿孔により広範な皮下膿瘍を形成した $\mathrm{S}$ 状結腸間膜内ヘルニアの 1 例を経験した．Ｓ状結腸間 膜内ヘルニアは稀な疾患てあるが，その中でも自験例 は間膜欠損孔が小さく, Richter 型に腸管が嵌頓し, 後

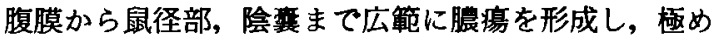
て特異な病態を呈した 1 例であった。

\section{文献}

1) Benson JR, Killen DA: Internal hernias involving the sigmoid mesocolon. Ann Surg 159 : 382-384, 1964

2) Steinke CR: Internal hernia. Arch Surg 25 : 909-925, 1932

3) Hansmann GH, Morton SA : Intra-abdominal hernia : Report of a case and the literature. Arch Surg 39 : 973-986, 1939

4）天野純治：内へルニアの診断と治療。外科 Mook $52: 85-96,1989$

5）瀬藤晃一，相生 仁, 平石 深他：きわめてまれな 内ヘルニアの1例. 外科 $40: 1391-1393,1978$

6）村上茂樹, 岡島邦雄, 磯崎博司他：S 状結腸間膜内 ヘルニア嵌頓によるイレウスの1例. 日臨外医会 誌 $57: 1983-1987,1996$

7）山口聖一, 横山孝一, 溙原 徹他：S 状結腸間膜简 ヘルニアの 1 例. 茨城臨医誌 $30: 82,1994$

8）神徳純一，中島䫓一郎，宮崎洋史他：S 状結腸間膜 简へルニアの1例. 群馬医 $60: 203-205,1994$

9）斎藤典才, 古田和雄, 横山 隆他：術前診断しえた $\mathrm{S}$ 状結腸間膜窝へルニアの1例一本邦報告例の検 討一. 外科 $59: 489-492,1997$

10）遠藤良幸, 吉田典行, 安藤善郎他：S 状結腸間膜裂 孔ヘルニアの 2 症例。日臨外医会誌 57(增刊号)： 549,1996

11）今里雅之, 林 恒男, 田中精一他：S 状結腸間膜内 ヘルニアの1例. 外科 $58: 493-495,1996$

12) Clemenz FW, Kemmerer DA : Internal hernias involving the sigmoid mesocolon. Arch Surg 159: 382-384, 1964

13）石井正一：S 状結腸間膜裂孔へルニアの治験例一 本邦腸間膜裂孔へルニアに関する文献的考察一。 外科治療 $26: 99-104,1972$

14）中井秀郎，石飛幸三，濱名元一他：S 状結腸間膜窝 ヘルニアの 1 例。日臨外医会誌 $45: 207,1984$ 


\title{
A CASE OF INTERMESOSIGMOID HERNIA CAUSING WIDE RANGE OF RETROPERITONEAL ABSCESS
}

\author{
Masayoshi IDO, Hisaya KURODA, Akihiro ITO, Kenji KATO, Hiroyuki KATO, \\ Makoto IWATA, Tatsushi NAGANUMA, Hideto SASAKI and Kenji FUJIMORI \\ Department of Surgery, Saiseikai Matsusaka General Hospital
}

A 66-year-old man was admitted to the hospital because of vomiting, abdominal distension, and a swelling of the left scrotum which lasted for three days. Physically there were abdominal distension, flare and swelling of skin covering from the left flank to the inguinal region and scrotum. On blood chemistry, a remarkable increase in white blood cells, high level of CRP, and renal impairment were noted. Abdominal X-ray film revealed intestinal obstraction. CT visualized a wide range of retroperitoneal abscess extending from the left perirenal retroperitoneum to inguinal region and a swelling of the left spermatic cord. With a diagnosis of intestinal obstruction due to perforation of incarcerated inguinal hernia and retroperitoneal abscess, an emergency operation was performed. Upon laparotomy, no inguinl hernia was present and a defect on mesentery in the vicinity of the root of sigmoid mesentery was found. And the ileum perforated and incarcerated into the defect in the manner of Richter type, forming the retroperitoneal abscess. A diagnosis of intermesosigmoid hernia was made, and the perforated site of the ileum and the mesentery defect were closed by sutures, and abscess drainage was performed. The patient' $s$ life was successfully saved. There have been only 38 cases of the hernia involving the sigmoid mesocolon in the Japanese literature so far. Especially, this case is very rare that caused perforation of the incarcerated intestinal hernia forming retroperitnoneal abscess. 